\title{
Barriers and Opportunities for Sustainable Food Systems in Northeastern Kansas
}

\author{
Hikaru Hanawa Peterson ${ }^{1}{ }^{*}$, Theresa Selfa ${ }^{2}$ and Rhonda Janke ${ }^{3}$ \\ 1 Department of Agricultural Economics, Kansas State University, Manhattan, KS, 66506, USA \\ 2 Department of Sociology, Anthropology, and Social Work, Kansas State University, Manhattan, \\ KS, 66506, USA; E-Mail: tselfa@ksu.edu \\ 3 Department of Horticulture, Forestry, and Recreation Resources, Kansas State University, \\ Manhattan, KS, 66506, USA; E-Mail: rrjanke@ksu.edu \\ * Author to whom correspondence should be addressed; E-Mail: hhp@ksu.edu; \\ Tel.: +1-785-532-1509; Fax: +1-785-532-6925.
}

Received: 19 November 2009 / Accepted: 6 January 2010 / Published: 12 January 2010

\begin{abstract}
Survey responses of producers and institutional buyers in northeastern Kansas (United States) were analyzed to understand barriers and opportunities for sustainable food systems in the region where their emergence has been limited. Producers and buyers identified barriers previously noted regarding mismatches of available quantities and prices. Producers' enthusiasm to supply locally exceeded buyers' interest to source locally. Transportation was identified as one of the major concerns by producers, and their responses to choice tasks revealed producers' preferences to sell locally while pricing their products to secure sales revenue and to cover their logistics expenses at least partially.
\end{abstract}

Keywords: barriers; choice tasks; farm-to-institution; survey; sustainable food systems; Great Plains

\section{Introduction}

A food system links producers of food and consumers, involving production, processing, distribution, consumption, and waste disposal processes [1]. The principle of sustainability in food systems in the United States appears to extend from the movement seeking sustainability in agriculture, reflecting concerns for environmental degradation around the 1970s and for distressed rural economies 
stemming from the 1980s farm crisis [2]. Sustainable agriculture consists of three principles: economically viable farm operations, social justice, and ecological responsibility [3]. Sustainable food systems would imply that farming practices would be ecologically sustainable and farm products would be purchased in ways that promote economic viability of farm operations. Local food systems have been conceptualized as sustainable food systems that are geographically contained, where the food is sourced closer to consumption, minimizing fuel use and marketing expenses associated with distance and providing better returns to farmers [2,4]. The equation of local with sustainable food systems remains a topic of academic discourse [5,6].

While sustainability of local food systems remains debatable, these geographically focused food systems have noticeably emerged in many parts of the country in recent years, fueled by increasing consumer interest in locally grown food [7]. Advocates of local foods call for supporting the local economy and family farms, while enjoying fresh, better tasting food and minimizing the distance food travels from field to plate (e.g., FoodRoutes [8]). Interestingly, the attributes consumers seek out in local foods are not fully understood. Darby et al. [9] found that consumers' demand for locally produced foods is independent of other attributes such as freshness, and Pirog [10] found higher interest among consumers for locally grown foods than for foods with environmental and social attributes but which were not grown locally. But, other studies reported that local labeling did not yield any premium for products of equal quality [11] or that attributes such as freshness or appearance were more important than being local [12]. Moreover, the definition of local appears context-specific and nowhere unified (e.g., [13-18]).

A map of farms and retail outlets that offer sustainably grown foods according to LocalHarvest, Inc. shows numerous activities along the western coast and eastern half of the US bordering the Great Plains region [19]. The Great Plains "stretches westward from the Missouri River at Omaha and Kansas City to the Rocky Mountains, and northward from the Texas Panhandle into the Canadian Prairie Provinces" [20]. Along its eastern border, the nascent sustainable food movement can be observed. In northeastern Kansas, the city of Lawrence is considered a geographical center of local food networks in Kansas, with an active consumer cooperative grocery store and the downtown district with several food service operations contributing to the network [21]. Supermarkets in the Kansas City area are partnering with producers like Good Natured Family Farms, a cooperative of 18 family farms in Kansas and Missouri [22], to promote their local food programs. These endeavors of localizing food procurement can be seen as part of advancement towards a larger goal of making the food system more sustainable.

The existing literature on sustainable food systems has naturally studied regions with relatively more established sustainable food systems. Indeed, numerous studies have examined cases in California, the Pacific Northwest, the Northeastern US, and the upper Midwest including Iowa. Yet, the development of food systems is conditioned by the natural and social environment inherent to their location [23]. The regions where the sustainable food systems are currently less developed share several commonalities. In the Great Plains, low population density implies that producers are likely to be located far from high concentrations of consumers, requiring additional cost to transport the goods from the farm to consumers. Agriculture in this region is distinctly industrial and relatively more commoditized than the rest of the country, specializing mostly in large-scale grains and livestock operations. Producers in regions where agricultural commodities have historically been produced to be 
exported to areas beyond the region tend to be less interested in producing for local markets $[7,16]$. Practitioners of alternative agricultural strategies in rural areas often find they must minimize association with urban "progressive" environmental or social movements in order to make their efforts more locally palatable to other farmers and consumers, or in many cases, deliver products to urban markets at great distance [23].

The objective of this study is to examine the barriers and opportunities for greater institutional sales as part of a sustainable food system in northeastern Kansas. To obtain a more complete picture, surveys were designed to collect views of both producers and buyers. Among the buyers, we focused on institutional buyers such as schools, university dining services, and restaurants, given the significance of the role played by institutions on food consumed in the US food system. Of $\$ 1.14$ trillion spent on all foods in 2007 , $49 \%$ was consumed away from home through institutions, compared to $0.4 \%$ consumed directly from farmers, manufacturers, or wholesalers [24]. Some scholars have described these institutional marketing arrangements as a vanguard in efforts to create alternative and more sustainable food systems [25] and as a significant contemporary social movement [26]. While we are aware of the recent discussions about the broader political context of the emergence of farm-to-school and farm-to-college initiatives [27,28], our paper is not focused on these issues, but rather uses empirical data to examine the practical and logistical barriers and opportunities for expanding institutional food procurement in Great Plains.

We also focused our efforts in identifying the barriers faced by producers in participating in local food systems with a particular emphasis on logistics, which has not been studied extensively. We conjecture logistics is a critical deterrent to institutional sales and their role in local/sustainable food systems in many if not all areas, but particularly in vast areas such as the Great Plains region of the US. The spacious nature of the region implies travel time and fuel cost, which likely further discourages distribution of smaller, frequent volumes.

In the subsequent section, the literature on factors contributing to success and demise of sustainable food systems is reviewed. Then, the survey instruments used in the study are described. After describing the characteristics of the respondents, we proceed to present the survey findings as they related to the local food system and the barriers faced by producers in terms of logistics.

\section{Previous Literature}

Within the broad array of efforts at bringing producers and consumers together in more sustainable food networks, programs to foster the marketing of locally produced food to institutional buyers have been recognized as novel means to offer a potentially large market for producers. Although arrangements are diverse, the most common type of institutional purchasing has been through farm-to-school programs that aim to bring more "local" food into the school food programs. In fact, these programs have proliferated in the past several years, with estimates of over 1,000 programs active in 34 states [29]. Interest in farm-to-school has emerged from concerns about the decline in the viability of local agricultural production in many regions, along with concerns about children's health as related to diet and lack of access to fresh foods [30,31]. Unlike other sustainable food system initiatives, such as farmers' markets and community supported agriculture (CSA), farm-to-school programs have received relatively less attention in the academic literature [25]. 
A recent review of research on farm-to-institution marketing highlighted several areas of convergence in findings on these programs [31]. In particular, the review summarized the current knowledge on perceived interest, benefits, barriers, and opportunities in farm-to-institution programs. These authors note that much of the research on farm-to-institution marketing programs has occurred in Midwestern states, with the greatest number of studies focused on Iowa, followed by Minnesota and Michigan. The majority of these studies were based on survey research of school food services directors, with response rates varying widely between $19 \%$ for a survey in the four-state region (IA, KS, NE, and $\mathrm{MN}$ ) to a $67 \%$ response rate among Oklahoma school district food service directors [31].

Most of the studies only looked at the opportunities and constraints faced by institutional buyers, although at least one surveyed farmers as well [32]. Although many believe that farm-to-school programs have potential to improve viability of small scale farms, data on the profitability for producers of participating in these programs are lacking [31]. Several other studies conducted in Wisconsin, California and Florida relied on qualitative research methods, especially interviews and facilitated discussions with stakeholders (both farmers and food buyers). In general, these studies indicate that farmers appear to be more interested in farm-to-institution marketing than are most institutional buyers (see references within Vogt and Kaiser [31]).

Factors that were shown to be significant in encouraging buyers to source regional foods were the type of food service. That is, food service directors, who worked independently with food providers, more often preferred local sources, as did those who had a clearer connection to agriculture. College/university food service directors in Iowa preferred local foods more than other buyers, such as school districts. Overall, however, for institutional buyers, the most important considerations in their buying decisions were quality, cost, and service, while locally grown was not especially important [31].

The review also found that while some food buyers may be interested in regional sourcing, a key barrier to regional procurement was the lack of infrastructure needed to locate produce and coordinate all aspects of distributing farm produce. Other barriers noted were lack of trained staff to process food, budget constraints, and limited storage and processing facilities. Another recent study which examined four food distributors involved in farm-to-school initiatives in the Upper Midwest and in the Northeastern US also pointed to budget constraints as the key obstacles for school districts incorporating more regional produce [25]. This study found that often school districts were forced to source produce through a federal government program over local suppliers due to cost.

For farmers, the major obstacle identified was a lack of year round availability of produce [31]. In response to the constraint posed by the lack of year round availability, farmers in Colorado expressed interest in the creation of a farmers' cooperative to organize large scale buying and distribution from multiple producers [2]. A recent study on consumer demand for extended season produce in Michigan found that consumers were interested and willing to pay more for local produce at the farmers' market, if the growing season for produce could be extended through techniques such as high tunnels [33]. Overall, these findings suggest the need for more logistical support and coordinated distribution channels to make farm-to-institution marketing more viable for both buyers and producers. 


\section{Producer and Buyer Surveys}

The surveys were designed to further our understanding of constraints faced by producers to supply to local markets and by institutional buyers to procure locally grown farm products. Both surveys included similar sets of questions to obtain respondent characteristics, their definitions of local markets, attitudes towards local food systems, and perceived barriers. In addition, the producer survey included general questions on their marketing practices and choice task questions designed to value the trade-offs producers faced in supplying to the local market in terms of logistics. The buyer survey included questions on their food procurement and preparation practices. The target population for our survey comprised of producers and institutional buyers in northeastern Kansas, which turned out to be a major challenge to reach.

Given our interest in local food systems, we narrowed our focus on farmers who produced to market and were interested in alternative marketing, excluding those who produced just for their personal consumption as well as large-scale, commodity producers. There were multiple overlapping but independent grower associations in the area, and we compiled contact information from members of Growing Growers (a new farmer training program in the area), attendees of the Great Plains Vegetable Growers Conference, and members of Kansas Fruit Growers and Vegetable Growers Associations. In addition, we also included vendors listed for farmers' markets in Kansas. The survey recipients would include growers in the adjacent state of Missouri and non-growers who could be selling non-farm products at farmers' markets. The first caveat was deemed irrelevant, since the Missouri producers in our sample would still be supplying to the Kansas City area, which is included in the study region. The second caveat was addressed by asking a screening question at the beginning of the survey to ensure that it was only completed by farmers, who currently produced or were planning to produce agricultural products to sell or that they would like to sell to local markets.

A total of 1,669 producer surveys were mailed out in November 2007. Over the subsequent month, the non-respondent recipients whose phone numbers were available were reached by phone with a request and reminder to mail back the survey. From these phone calls and the negative responses to the screening question, the maximum number of recipients who were producers was 1,309 , which is probably a high estimate for the target population. According to the 2007 Census of Agriculture, there were 473 vegetable farms and 432 fruit farms in Kansas [34]. We do not have an estimate of the number of dairy, meat, and other farmers who direct market, and likely there were more on our mailing list who were non-growers that sold value added products at farmers' markets. Ultimately, 192 usable responses were received (14.7\% response rate). Given the uncertainty of the exact number in our target population, this is a most conservative estimate of our response rate.

The target institutional buyers were limited to those in ten counties in northeastern Kansas along Kansas River Valley and the interstate highway. The target institution types included school districts, university dining, daycares, senior and group housing, hospitals, and restaurants. For all types but restaurants, phone directories and other publicly available lists were used to compile the list of institutions. For restaurants, the Greater Kansas City Chefs Association directory with about 400 members was used as a representative sample of independent restaurants in the study region. The buyer survey was decided to be administered online based on multiple considerations regarding the research budget, the response rate from the producer survey, and the work environment of the 
individuals we were trying to reach. To address the difficulty in reaching individuals within each institution who were responsible for food purchases, initial phone calls were made to the institutions to identify the individuals and their e-mail addresses. These phone calls were also used as a preliminary inquiry about local food use by these institutions to ensure relevance of the questions included in the actual survey.

In the end, the number of institutions compiled exceeded 300, but the number of individual e-mail addresses remained at 121. The buyer survey was conducted online from February through April of 2009. Despite numerous follow-up contacts, usable responses were limited to 36 out of 63 total responses. Relative to the individual e-mail addresses we gathered, 121, the useable response rate is $29.8 \%$. Considering the chefs' association listserv which contained about 400 members, the implied response rate diminishes to $6.9 \%$. For comparison, the previous surveys of institutional buyers by Gregoire and Strohbehm [35] and Starr et al. [2] had 19\% and 24\% response rates, respectively.

\section{The Producer Survey Respondents}

The characteristics of the producers who responded to the survey are summarized in Table 1 . They are presented alongside statistics for the small family, farming-occupation, low-sales farms from the 2004 Agricultural Resource Management Survey (ARMS) for reference, where small family, farming-occupation, low sales farms are defined as farms with gross sales under $\$ 100,000$, whose operators report farming as their major occupation [36]. The description fits the majority of our sample farmers, with $87.1 \%$ indicating their gross farm sales as under $\$ 100,000$. While the survey did not officially ask whether farming was their major occupation, the median work time allocated to farming was $60.0 \%$.

Almost $40 \%$ of the producers responding were female, and $58.2 \%$ had completed college education. The sample had a more equal representation of gender and higher educational attainment than the ARMS statistics. The age distribution was similar to the ARMS statistics, with the average producer being 56.4 years old and having 21.4 years of farming experience.

The average number of acres operated was 171 , with $62 \%$ of the respondents managing less than 50 acres. The sample farms are quite smaller than the ARMS farms, which likely included proportionally more grain farmers. Our sample farm size was more similar to that of the residential/lifestyle farms in the ARMS report, with mean of 163 and median of 67 acres [36, Table 1]. The average percentage of acres that were certified organic was $15.4 \%$ including acres in transition, with $7.8 \%$ of the respondents farming certified organic acres exclusively. The farm type by output is drastically different from that of statewide. With $68.2 \%$ and $30.2 \%$ respondents growing fresh vegetables and fruit, respectively, three out of four respondents were produce growers. One in five respondents produced ornamentals. The shares of producers of eggs, poultry, dairy, pork, and lamb/goat were much greater than the statewide as well, while there were proportionally less producing grains, hay, and beef, which are the primary crops of the state. In terms of the degrees of diversification, our sample distribution resembled that of ARMS closely. 
Table 1. Characteristics of the Producer Respondents $(n=192)$.

\begin{tabular}{|c|c|c|}
\hline & Sample & $\mathbf{U} \mathbf{S}^{a}$ \\
\hline \multicolumn{3}{|l|}{ Gender } \\
\hline Female & $38.9 \%$ & $11.0 \%$ \\
\hline Male & $61.1 \%$ & $89.0 \%$ \\
\hline \multicolumn{3}{|l|}{ Education } \\
\hline Less than high school & $1.6 \%$ & $11.2 \%$ \\
\hline High school degree & $13.6 \%$ & $50.6 \%$ \\
\hline Some college work or vocational degree & $26.6 \%$ & $18.9 \%$ \\
\hline College degree & $28.8 \%$ & \multirow{3}{*}{$19.3 \%$} \\
\hline Some postgraduate work & $8.7 \%$ & \\
\hline Postgraduate work & $20.7 \%$ & \\
\hline \multicolumn{3}{|l|}{ Age } \\
\hline Mean (years) & 56.4 & 57 \\
\hline$\%$ under 35 years & $3.9 \%$ & $4.1 \%$ \\
\hline$\%$ 35-44 years & $8.4 \%$ & $9.7 \%$ \\
\hline$\%$ 45-54 years & $31.8 \%$ & $20.5 \%$ \\
\hline$\%$ 55-64 years & $31.3 \%$ & $40.5 \%$ \\
\hline$\%$ over 65 years & $24.6 \%$ & $25.3 \%$ \\
\hline \multicolumn{3}{|l|}{ Years of farming experience } \\
\hline Mean (years) & 21.4 & \\
\hline Median (years) & 20.0 & \\
\hline$\%$ less than 5 years & $10.6 \%$ & \\
\hline \multicolumn{3}{|l|}{ Gross farm sales } \\
\hline Less than $\$ 2,500$ & $18.1 \%$ & \multirow{3}{*}{$47.1 \%$} \\
\hline$\$ 2,500-\$ 4,999$ & $10.5 \%$ & \\
\hline$\$ 5,000-\$ 9,999$ & $15.2 \%$ & \\
\hline$\$ 10,000-\$ 24,999$ & $18.7 \%$ & \multirow{2}{*}{$29.4 \%$} \\
\hline$\$ 25,000-\$ 49,999$ & $14.0 \%$ & \\
\hline$\$ 50,000-\$ 99,999$ & $10.5 \%$ & $23.5 \%$ \\
\hline$\$ 100,000-\$ 249,999$ & $9.9 \%$ & na \\
\hline Over $\$ 250,000$ & $2.9 \%$ & na \\
\hline \multicolumn{3}{|l|}{ Acres operated } \\
\hline Mean (acres) & 171.0 & 413 \\
\hline Median (acres) & 40.0 & 145 \\
\hline \multicolumn{3}{|l|}{$\%$ acres that are certified organic } \\
\hline Mean & $15.4 \%$ & \\
\hline Median & $0.0 \%$ & \\
\hline
\end{tabular}


sales through grower cooperatives were only $4.2 \%$, through retained ownership or commission merchants $4.7 \%$, and sales to brokers and packers was $9.4 \%$.

Table 2. Marketing Outlets Used by Producers $(n=192)$.

\begin{tabular}{ll}
\hline Direct sales to consumers: & \\
\hline Farmer's markets & $67.7 \%$ \\
CSA or subscription & $10.9 \%$ \\
Roadside stands/farm stores & $27.6 \%$ \\
U-Pick sales & $9.9 \%$ \\
Other direct sales & $43.8 \%$ \\
\hline Use of middle persons: & \\
\hline Growers' cooperatives & $4.2 \%$ \\
Wholesale buyers/brokers/packers & $9.4 \%$ \\
Retained ownership|commission merchant & $4.7 \%$ \\
\hline Sales to retail outlets: & \\
\hline Grocery stores & $20.8 \%$ \\
Food cooperatives & $8.9 \%$ \\
Restaurants & $27.1 \%$ \\
Institutions (such as schools and hospitals) & $5.7 \%$ \\
Other & $12.5 \%$ \\
\hline
\end{tabular}

\section{The Buyer Survey Respondents}

The characteristics of the buyer respondents are summarized in Table 3. Group housing and school districts comprised $58.4 \%$ of the responses from the institutional buyers, followed by daycare centers $(11.1 \%)$, retirement homes $(11.1 \%)$, university dining $(8.3 \%)$, a restaurant $(2.8 \%)$, and a senior center $(2.8 \%)$. The number of meals served varied from 0 to 10,000 breakfasts, 0 to 14,500 lunches, and 0 to 150 dinners. The 2008 food budget for these institutions varied from $\$ 1,000$ to $\$ 9$ million (the latter was for a school district), with median of $\$ 81,500$ and totaling $\$ 25.4$ million. More than $80 \%$ of the individuals responding to this survey on behalf of their institutions were responsible for $100 \%$ of their food budget, with $52.8 \%$ of the individuals having more than 10 years of experience in food purchasing.

Table 3. Characteristics of the Buyer Respondents $(n=36)$.

\begin{tabular}{ll}
\hline Institutional type & \\
\hline Group Housing & $30.6 \%$ \\
School District & $27.8 \%$ \\
Daycare & $11.1 \%$ \\
Retirement Home & $11.1 \%$ \\
University Dining & $8.3 \%$ \\
Restaurant & $2.8 \%$ \\
Senior Center & $2.8 \%$ \\
\hline
\end{tabular}


Table 3. Cont.

\begin{tabular}{lrr}
\hline \# Meals served & Mean & Median \\
\hline Breakfast & 722 & 50 \\
Lunch & 1,346 & 91 \\
Dinner & 53 & 0 \\
\hline 2008 Food budget & \\
\hline Mean & $\$ 806,934.14$ \\
Median & $\$ 81,500.00$ \\
\hline \% Budget responsible by the respondent & \\
\hline Mean & \\
Median & $100.0 \%$ \\
\hline \# Years of experience in food purchasing & 12.5 \\
\hline Mean (years) & 11.0 \\
Median (years) & \\
\hline
\end{tabular}

Table 4. Food Ordering by the Buyer Respondents $(n=36)$.

\begin{tabular}{|c|c|c|c|c|c|}
\hline \multicolumn{6}{|l|}{ Frequency of ordering } \\
\hline Daily & \multicolumn{5}{|c|}{$8.3 \%$} \\
\hline Every $2-3$ days & \multicolumn{5}{|c|}{$25.0 \%$} \\
\hline Once a week & \multicolumn{5}{|c|}{$44.4 \%$} \\
\hline Every 2-3 weeks & \multicolumn{5}{|c|}{$11.1 \%$} \\
\hline Once a month & \multicolumn{5}{|c|}{$2.8 \%$} \\
\hline Other & \multicolumn{5}{|c|}{$8.3 \%$} \\
\hline \multicolumn{6}{|c|}{ Ordering method (multiple choices allowed) } \\
\hline Face-to-face visits & \multicolumn{5}{|c|}{$66.7 \%$} \\
\hline Phone & \multicolumn{5}{|c|}{$47.2 \%$} \\
\hline Website & \multicolumn{5}{|c|}{$30.6 \%$} \\
\hline E-mail & \multicolumn{5}{|c|}{$25.0 \%$} \\
\hline Fax & \multicolumn{5}{|c|}{$16.7 \%$} \\
\hline \multicolumn{6}{|c|}{ Time between delivery and use (\% respondents) } \\
\hline & $\begin{array}{c}\text { Same } \\
\text { day }\end{array}$ & $\begin{array}{c}1-2 \\
\text { days }\end{array}$ & $\begin{array}{l}3-6 \\
\text { days }\end{array}$ & $\begin{array}{c}1-2 \\
\text { weeks }\end{array}$ & $\begin{array}{l}1 \text { month } \\
\text { or more }\end{array}$ \\
\hline Bread/pasta/rice & $11.1 \%$ & $36.1 \%$ & $30.6 \%$ & $16.7 \%$ & $5.6 \%$ \\
\hline Fruit/vegetable & $13.9 \%$ & $50.0 \%$ & $25.0 \%$ & $11.1 \%$ & $0.0 \%$ \\
\hline Meats/seafood & $11.1 \%$ & $25.0 \%$ & $38.9 \%$ & $16.7 \%$ & $8.3 \%$ \\
\hline Dairy & $17.1 \%$ & $34.3 \%$ & $45.7 \%$ & $2.9 \%$ & $0.0 \%$ \\
\hline Eggs & $11.4 \%$ & $34.3 \%$ & $40.0 \%$ & $14.3 \%$ & $0.0 \%$ \\
\hline Condiments & $8.3 \%$ & $13.9 \%$ & $25.0 \%$ & $16.7 \%$ & $36.1 \%$ \\
\hline
\end{tabular}

Table 4 summarizes the food procurement process used by the buyer respondents. Nearly half of these institutions placed their food orders once a week (44.4\%), followed by every 2-3 days (25.0\%), and every $2-3$ weeks $(11.1 \%$ ), with $8.3 \%$ of the respondents ordering daily. Most popular ordering methods were "face-to-face" visits and phone used by $66.7 \%$ and $47.2 \%$ of the respondents, 
respectively, followed by online (30.6\%) and e-mail (25.0\%), with approximately 2 out of 3 respondents using more than one method. The length of time between delivery and use of food items varied from "same day" to "1 month or more" depending on the institution and food items. Dairy, fruit and vegetable, and eggs were typically used within six days of delivery by over $85 \%$ of the respondents. Bread/pasta/rice and meats/seafood were used within six days of delivery by about $75 \%$ of the respondents. More than one third of the respondent stored condiments for a month or more before use.

\section{The Local Market for the Respondents}

The survey responses revealed a consistency in the definition of a "local" market among most producers and buyers in our samples (Table 5). Producers were asked in an open-ended question what a local market meant to them. Three out of four respondents responded in terms of distance, while $15.8 \%$ mentioned their county of residence or neighboring counties. Of those who responded in terms of distance, $68.5 \%$ responded as a radius of 60 miles or within one hour of driving and $18.9 \%$ responded as a radius of between 75 and 100 miles. Buyers were asked to choose from a multiple choice of definitions. Thirty-six percent chose "within my county" and $47.2 \%$ chose "within a 100-mile radius". Thus, there was a rough consensus among about $80 \%$ of the producers and buyers to consider a 100-mile radius as local, which is about the same size as our target region: the area along the Kansas River Valley spanning from Kansas City, Kansas/Missouri in the east to Manhattan, Kansas in the west.

Table 5. Defining "Local".

\begin{tabular}{cr}
\hline Producer (n = 192) & \\
\hline Distance (one way) & $75.8 \%$ \\
Less than 60 miles / within 1 hour & $68.5 \%$ \\
75-100 miles & $18.9 \%$ \\
150-200 miles / 2 to 5 hours & $12.6 \%$ \\
County of residence/neighboring counties & $15.8 \%$ \\
Farmers' markets/city/state & $8.5 \%$ \\
\hline Institutional Buyer (n = 36) & $36.1 \%$ \\
\hline Within my county & $47.2 \%$ \\
Within a 100 mile radius & $5.6 \%$ \\
Within a 5-hour drive one way & $8.3 \%$ \\
Within my state & $2.8 \%$ \\
Within the 48 contiguous states &
\end{tabular}

Most respondents were participating in the local food system (Table 6). The average percentage of farm products producers marketed to the county of their residence was $48.1 \%$, followed by $35.6 \%$ to neighboring counties. Sixty-four percent of the buyers indicated buying "locally produced foods" at least once. Of these buyers, 56.5\% sourced local foods through their regular suppliers, and $47.8 \%$ purchased directly from a farmer. 
Table 6. Participation in the Local Food System.

\begin{tabular}{cc}
\hline Producer $(\mathbf{n}=\mathbf{1 9 2})$ & Mean \\
\hline Market area & \% farm products sold \\
In your county & $48.1 \%$ \\
In neighboring counties & $35.6 \%$ \\
In the states of Kansas and/or Missouri & $10.3 \%$ \\
In the United States (not KS or MO) & $4.1 \%$ \\
Outside the US & $0.1 \%$ \\
Unknown or handled through intermediary & $1.8 \%$ \\
\hline Institutional Buyer (n = 36) & $\%$ respondents \\
\hline Has used locally produced foods & $63.9 \%$ \\
Yes & $36.1 \%$ \\
No & $\%$ respondents (n = 23) \\
Source of local foods (multiple choice allowed) & $47.8 \%$ \\
Directly from a farmer & $56.5 \%$ \\
Through our regular supplier & $8.7 \%$ \\
Through a new supplier & $8.7 \%$ \\
Other &
\end{tabular}

The buyers were asked to evaluate their perceived quality of local foods relative to similar non-local foods. The responses suggested that the overall experiences with local foods have been favorable (Table 7). On average, the buyers who had bought local foods rated local foods equally or better in terms of product uniformity, reliability, freshness, nutritional value, flavor, ease of handling, and safety. Interestingly, those without experience gave statistically higher average scores for local foods than those with experience for freshness and flavor, and a statistically lower average score for reliability.

Table 7. Perception of Local Foods Compared to Similar Non-Local Items. ${ }^{a}$

\begin{tabular}{|c|c|c|c|c|}
\hline \multirow[b]{2}{*}{ Product is uniform } & \multicolumn{2}{|c|}{$\begin{array}{c}\text { With experience } \\
(n=23)\end{array}$} & \multicolumn{2}{|c|}{$\begin{array}{c}\text { No experience } \\
(n=13)\end{array}$} \\
\hline & 3.05 & $x$ & 2.89 & $x$ \\
\hline Product is reliable & 3.22 & $x^{* * *}$ & 2.57 & $y^{* * * *}$ \\
\hline Product is fresh & 3.60 & $y^{* *}$ & 3.89 & $x^{* *}$ \\
\hline Contains all nutritional value & 3.39 & $x$ & 3.44 & $x$ \\
\hline Product is flavorful & 3.62 & $y^{*}$ & 3.89 & $x^{*}$ \\
\hline Ease of handling & 3.04 & $x$ & 3.00 & $x$ \\
\hline Measures up to safety standards & 3.23 & $x$ & 3.00 & $x$ \\
\hline
\end{tabular}


A series of value statements were included in both the buyers' and producers' surveys, which were intended to measure the level of agreement between buyers and producers on the importance of "local" food and the relative importance of different attributes to both groups of respondents. The respondents were asked to indicate their level of accordance with a 5-point scale $(1=$ strongly disagree, $5=$ strongly agree). The only statements on both surveys that elicited similar levels of agreement from buyers and producers were: "I have a sense of belonging to my local community" for growers and "Our institution has a sense of belonging to our local community" by institutional food buyers (Table 8).

Table 8. Value Statements ( 5 = Strongly Agree, $1=$ Strongly Disagree).

\begin{tabular}{|c|c|c|}
\hline \multicolumn{3}{|l|}{ Producer: } \\
\hline I have a sense of belonging to my local community. & 4.29 & $\bar{c}$ \\
\hline Knowing individual consumers is important to me. & 4.53 & $b$ \\
\hline I want consumers to know if their food came from my farm. & 4.73 & $a$ \\
\hline $\begin{array}{l}\text { Labeling my products as "local" will make my products more } \\
\text { attractive to consumers. }\end{array}$ & 4.33 & $c$ \\
\hline Selling what I produce to the local community is important to me. & 4.54 & $b$ \\
\hline \multicolumn{3}{|l|}{ Institutional Buyer: } \\
\hline Our institution has a sense of belonging to our local community. & 4.36 & 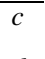 \\
\hline $\begin{array}{l}\text { Knowing the sources of the food we serve is important to } \\
\text { our institution. }\end{array}$ & 4.03 & $d$ \\
\hline We want our clients to know where their food came from. & 3.67 & $f$ \\
\hline Products labeled as "local" are more attractive to our institution. & 3.58 & $f$ \\
\hline $\begin{array}{l}\text { Purchasing what is produced in the local community is important } \\
\text { to our institution. }\end{array}$ & 3.58 & $f$ \\
\hline Supporting local agriculture is important to our institution. & 3.86 & $e$ \\
\hline
\end{tabular}

Note: The shared superscripts are statistically not different at the $1 \%$ level based on Tukey's test.

Every other paired statement elicited statistically different responses from growers and buyers (p-values less than 0.0001), such as: "Knowing individual consumers is important to me" was rated with a score of 4.33 by producers, while buyers responded with a 4.03 to the following statement: "Knowing the sources of the food we serve is important to our institution." Similarly, producers strongly agreed (4.54) that "Selling what I produce to the local community is important to me," while buyers only moderately agreed (3.58) that "Purchasing what is produced in the local community is important to our institution." While the producers thought "Labeling my products as "local" will make my products more attractive to consumers" (a score of 4.33), the institutional buyers' average score was only 3.58 regarding the statement "Products labeled as "local" are more attractive to our institution." Clearly it appears that while both buyers and producers feel it is important to belong to their community, buyers do not translate the importance of community ties to the support of local agriculture and farmers. Indeed, the average score for "Supporting local agriculture is important to our institution" was 3.86 .

Regarding barriers to participating in a local food system, producers and buyers shared a similar concern suggesting lack of market information and coordination (Table 9). The buyers' top concerns 
were not knowing potential suppliers (identified by $63.9 \%$ of the respondents allowed to choose multiple choice), prices being too high or too variable $(47.2 \%)$, and inconsistent or inadequate supply (41.7\%). These concerns are largely consistent with other studies [25,32,37]. These concerns could be addressed at least in part by readily available market information on prices and quantities being exchanged in the local markets, providing more transparency. Several studies suggest that institutional buyers would be more likely to source regional foods if they were available through existing vendors and/or if new brokering arrangements could be set up, to allow institutional buyers to purchase quantities they require $[25,31]$.

Table 9. Barriers to Participating in the Local Food System.

\begin{tabular}{lr}
\hline Producers (n = 192) & \\
\hline Too small of a quantity & $50.5 \%$ \\
Lack of year-round production & $34.4 \%$ \\
Transportation means / time & $24.5 \%$ \\
Insufficient time to produce / to contact buyers & $24.0 \%$ \\
Low price & $21.4 \%$ \\
Don't know where to find local buyers & $14.6 \%$ \\
Buyers backing out & $11.5 \%$ \\
Too large of a quantity & $9.9 \%$ \\
Buyers want liability insurance & $8.3 \%$ \\
Buyers want uniform boxes / packaging & $7.8 \%$ \\
Labor & $4.2 \%$ \\
Immature market (false local claims) & $3.6 \%$ \\
Age & $2.1 \%$ \\
\hline Buyers $\mathbf{n}$ 36) & $63.9 \%$ \\
My current suppliers do not carry local / Do not know & \\
potential suppliers & $47.2 \%$ \\
Price is too high / too variable & $41.7 \%$ \\
Inconsistent / inadequate supply & $25.0 \%$ \\
We've just never done this before & $19.4 \%$ \\
They might not be delivered as scheduled & $16.7 \%$ \\
We do not have adequate storage space & $5.6 \%$ \\
We lack labor to prepare & $5.6 \%$ \\
Sub-standard quality & $2.8 \%$ \\
Lack of our interest & $0.0 \%$ \\
We lack facilities to prepare &
\end{tabular}

The producers' top concerns were their quantities of production being too small for institutional buyers or too large for local buyers $(50.5 \%$ and $9.9 \%$, respectively), lack of year-round production $(34.4 \%)$, transportation means or time $(24.5 \%)$, insufficient time to produce or to find local buyers $(24.0 \%)$, and low prices in the local outlets $(21.4 \%)$. These concerns mirror those identified in another study [32], in which the lack of year-round availability, lack of a dependable market, and 
inability to produce sufficient quantity were the top barriers for producers, with the notable exception of transportation and time constraint.

\section{Producers' Conundrum}

Supplying to a local food system typically implies more frequent marketing in smaller volume than conventional marketing outlets. Previous literature suggests that the logistics of getting food from farms to schools is a key constraint for developing and maintaining these marketing arrangements [25,35,37], and one out of four producers in our sample indicated transportation as a major barrier. Thus, the management of logistics critically determines whether it is feasible for a time-constrained producer, as revealed above, to participate in the local food system. Anecdotal evidence suggests that producers are willing to drive to their market expending their time and physical travel costs. But, there is always risk of not being able to generate sufficient revenue due to factors beyond producers' control.

To analyze the producers' conundrum, we asked the respondents to indicate the smallest amount of gross sales revenue that they would consider worthwhile marketing their products (Table 10). The majority of growers $(71.2 \%)$ were willing to make a delivery spending one hour one-way for $\$ 100$ to $\$ 1,000$ gross sales, and $19.2 \%$ were willing for sales worth $\$ 10$ to 100 . If products were picked up at the farm, the minimum value decreased in general, with $87.0 \%$ willing to deal with $\$ 100$ or less in gross sales.

Table 10. The Smallest Sales Producers Consider Worthwhile to Market.

\begin{tabular}{lcc}
\hline & $\begin{array}{l}\text { If producers traveled one } \\
\text { hour one-way to deliver }\end{array}$ & $\begin{array}{l}\text { If products were picked } \\
\text { up at farm }\end{array}$ \\
\hline Gross sales & $(\mathrm{n}=125)$ & $(\mathrm{n}=132)$ \\
$\$ 1-10$ & $2.4 \%$ & $42.7 \%$ \\
$\$ 10-100$ & $19.2 \%$ & $44.3 \%$ \\
$\$ 100-1,000$ & $71.2 \%$ & $9.2 \%$ \\
$\$ 1,000-5000$ & $4.0 \%$ & $0.8 \%$ \\
$\$ 5,000-10,000$ & $1.6 \%$ & $1.5 \%$ \\
$>\$ 10,000$ & $1.6 \%$ & $2.3 \%$ \\
\hline
\end{tabular}

Another way to quantify the trade-offs producers make is through a series of designed choice task questions. The producers were asked to consider a situation where they had a vehicle-load of a product that must be sold within the next 10 days, and offers for this product varied by the unit price, volume, the delivery arrangement, and the type of buyer. To simplify, we asked them to assume that they considered $\$ 10$ per unit as a fair value for the product, but the offer price could vary between $\$ 8$ and $\$ 12$. The sales volume could be a full-, half-, or quarter-load of their vehicle's capacity. The producers were asked to adjust the units of their products so that $\$ 10$ would be relatively realistic, with examples of a bag of potatoes or a quarter of a lug of peaches. Thus, the number of units per load was not specified. The delivery options were either the producer drove 1 or 2 hours one way to the delivery point, or that the buyer would pick up from the producer's premise. The buyer could be a locally-based 
business with at most a few store locations or a chain operation of a national- or regional-franchise. There were 18 choice tasks designed using an orthogonal factorial design, which were divided into two blocks; each respondent was presented with one of the blocks with 9 choice tasks. Figure 1 is an example choice task.

Figure 1. Example Choice Tasks.

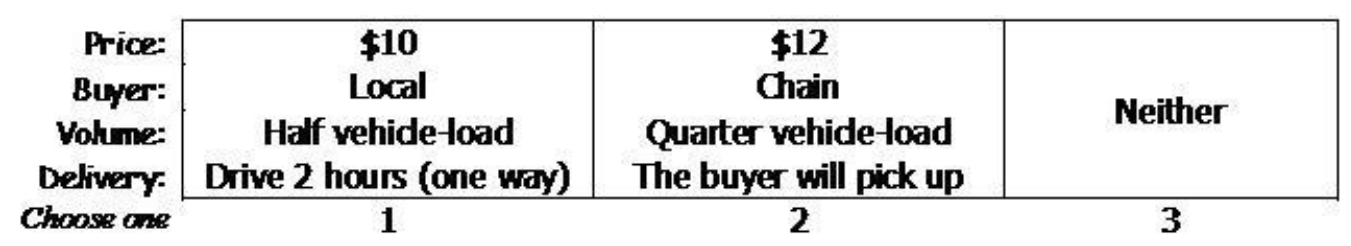

The responses to these choice tasks were analyzed using conditional logit model [38], which estimates utility functions of attributes relative to a base set of attributes. The base attributes in the current analysis were specified as a full vehicle load sold to a non-local buyer. The producers' implicit valuations for the departures from the base attributes were computed from the parameter estimates as the negative of ratios between the coefficients on the attributes and price. The values for the delivery options were calculated as differences from the pickup option.

The estimation results, presented in Table 11, show that the average producer in the sample preferred supplying to local buyers and was willing to take a $\$ 2.43$ discount per unit of a product valued at $\$ 10$, or roughly a $25 \%$ discount relative to selling to a non-local customer. Relative to having a full-load of their vehicle for sale, the producers wanted to charge close to a 50\% premium for their quarter-vehicle load and about a $25 \%$ premium for their half-vehicle load. Clearly, the producer decisions were defined in terms of total revenue that could be generated from a delivery route. They were willing to sacrifice per unit price if they could sell a larger quantity.

Table 11. Conditional Logit Estimates of Producer Preferences for Marketing Options. ${ }^{a}$

\begin{tabular}{lccc}
\hline Variable & Parameter estimate & Standard error & Producers' value \\
\hline rice & 0.3075 & 0.0332 & \\
Local & 0.7472 & 0.0910 & $-\$ 2.43$ \\
Quarter-load & -1.4087 & 0.1436 & $\$ 4.58$ \\
Half-load & -0.7455 & 0.1107 & $\$ 2.42$ \\
Pickup & -0.9888 & 0.2725 & \\
Drive 1 hour & -2.3572 & 0.3037 & $\$ 4.45$ \\
Drive 2 hours & -3.3926 & 0.3493 & $\$ 7.82$ \\
\hline
\end{tabular}

${ }^{a} 1,354$ observations, log-likelihood function $=-1,296$, McFadden's likelihood ratio index $=0.129$.

Regarding travel time, relative to pick-up on premise, the producers on average demanded $\$ 4.45$ per unit to drive for one hour and $\$ 7.82$ per unit to drive for two hours one way to sell their products. This is consistent with an average score of 4.15 that producers indicated (with a scale of 5 equaling strongly agree and 1 equaling strongly disagree) to the statement "Fuel prices affect my decision about how far to transport my product to market." Assuming that one can travel 50 miles in an hour, their response implies per-unit delivery cost of 4.5 cents per mile for a 100-mile round trip or 3.9 cents per mile for 
a 200-mile round trip. This might be sufficient to cover fuel costs if their minimum load consisted of 4 units (e.g., if gasoline cost $\$ 3$ per gallon and the gas mileage for the vehicle was 22 miles per gallon, the fuel costs of a 100-mile round trip would be 13.6 cents per mile). The load would need to be sufficiently larger if producers intended to recover their time expense.

\section{Discussion and Conclusions}

Despite the consensus on the definition of their local market and active participation by both producers and institutional buyers, the survey responses revealed a gap between levels of producers' enthusiasm to supply locally and buyers' interest to source locally. Overall, this gap has been highlighted in other related research, although there are clear differences among types of institutional buyers in terms of their interest in buying locally. Researchers in Iowa noted that college and university institutional food buyers who purchase local food state their reasons for doing so as the importance of supporting local farmers and the local economy [39]. However, it appears that supporting the local farmers and local economy does not factor as strongly for other institutional buyers, which was revealed in our research as well. Making a clearer connection between local food sourcing and supporting the local economy is one suggestion for increasing institutional purchasing and might help to overcome some of the barriers.

In addition, in alignment with many other studies, there is a need for research and policy interventions to assist in streamlining some of the logistical challenges that currently impede institutional purchasing and selling. One suggestion is to work to incorporate local foods into traditional distribution channels [25], while others suggest the need for state-level policy interventions. The proposed policy interventions include requiring state institutions, such as schools, to purchase a set percentage of available local foods, and mounting state level promotional campaigns on the use of local foods by various institutions [2]. A search of the Healthy Community Design and Access to Healthy Food Legislation Database [40] under the topic area of "agriculture/local food" yielded 655 pieces of legislation to support local food that were considered by states since 2004 or an average of 109 per year. In 2009, 36 states (Kansas not being among them) had some sort of initiative, and 27 of these proposed bills passed and were on their way to becoming law. These ranged from bills mandating that state agencies track and report local food purchases, to requiring a certain $20 \%$ of food purchased by state agencies be sourced locally by 2020 , to assistance with coordinating local purchases by schools, hotels, and restaurants and other businesses.

While producers are shown to be more enthusiastic and willing to participate in institutional food sales, there is obviously a need for more research exploring both the potential benefits for producers and particular constraints they face. While farm-to-institution programs have received relatively less attention than other types of marketing arrangements in the literature on local and sustainable food systems, producers' needs have been much less explored than have buyers' needs in this research [31]. The findings from the last section further support producers' clear preferences to participate in a local food network. The system, particularly in its emergence, mostly expects the producers to bear the cost of logistics. Not surprisingly, they have reservation prices for the services they provide. Our estimates of these reservation prices provide a useful first step, but clearly much more research is needed. The 
question remains whether the producers' reservation prices are indeed sufficient to maintain and promote the economic viability of their operations.

In order to overcome these barriers, contributions to sustainable food systems need to be presented as business opportunities for new and existing producers, distributors, and institutional users. All current and potential players in the system should be involved in developing solutions to the conundrum. Production and consumption are part of a common system [41], and sustainable solutions will not be developed for one sector in isolation from another, or without considering the ultimate impact on the environment, both physical and social. Many research questions remain to seek the ultimate structure of sustainable food systems. One such quest would identify the scope of a local food network that optimizes the degree of sustainability in terms of fuel use and farm economies.

\section{Acknowledgements}

The grant funding from the Center for Engagement at Kansas State University is gratefully acknowledged.

\section{References and Notes}

1. Robles, C. Sustainable Food Systems-Why Are Sustainable Food Systems Important? 2008; Available online: http://www.faqs.org/nutrition/Smi-Z/Sustainable-Food-Systems.html (accessed on 1 June 2009).

2. Starr, A.; Card, A.; Benepe, C.; Auld, G.; Lamm, D.; Smith, K.; Wilken, K. Sustaining local agriculture: barriers and opportunities to direct marketing between farms and restaurants in Colorado. Agric. Human Values 2003, 20, 301-321.

3. Gold, M.V. Sustainable Agriculture: Definitions and Terms; Special Reference Briefs Series NO. SRB 99-02; National Agricultural Library, Agricultural Research Service, U.S. Department of Agriculture: Beltsville, MD, USA, 1999; Available online: http://www.nal.usda.gov/afsic/ AFSIC_pubs/srb9902e.htm (accessed on 31 May 2009).

4. Kloppenburg, J., Jr.; Hendrickson, J.; Stevenson, G.W. Coming in to the foodshed. Agric. Human Values 1996, 13, 33-42.

5. Hinrichs, C.C. The practice and politics of food system localization. J. Rural Stud. 2003, 19, 33-45.

6. Winter, M. Embeddedness, the new food economy and defensive localism. J. Rural Stud. 2003, 19, 23-32.

7. Schneider, M.L.; Francis, C.A. Marketing locally produced foods: consumer and farmer opinions in Washington County, Nebraska. Renew. Agr. Food Syst. 2005, 20, 252-260.

8. FoodRoutes. There Are Many Good Reasons to Buy Locally Grown Food; 2009; Available online: http://www.foodroutes.org/whycare1.jsp (accessed on 2 June 2009).

9. Darby, K.; Batte, M.T.; Ernest, S.; Roe, B. Decomposing local: a conjoint analysis of locally produced foods. Amer. J. Agr. Econ. 2008, 90, 476-486.

10. Pirog, R. Ecolabel Value Assessment Phase II: Consumer Perceptions of Local Foods; Leopold Center for Sustainable Agriculture, Iowa State University: Ames, IA, USA, 2004; Available 
online: http://www.leopold.iastate.edu/pubs/staff/files/050504_ecolabels2.pdf (accessed on 31 May 2008).

11. Brown, C. Consumers' preferences for locally produced food: a study in southeast Missouri. Am. J. Alternative Agr. 2003, 18, 213-224.

12. Campbell, R.G.; Nelson, B.L.; Ebel, R.C.; Dozier, W.A.; Adrian, J.L.; Hockema, B.R. Fruit quality characteristics that affect consumer preferences for satsuma mandarins. HortScience 2004, 39, 1664-1669.

13. Harris, B.; Burress, D.; Mercer, S.; Oslund, P.; Rose, C. Kaw Valley Focus Groups on Local and Organic Produce; IPPBR Report No. 254B; University of Kansas: Lawrence, KS, USA, 2000; Available online: http://www.ipsr.ku.edu/resrep/pdf/m254B.pdf (accessed on 1 June 2008).

14. Guptill, A.; Wilkins, J.L. Buying into the food system: trends in food retailing in the US and implications for local foods. Agric. Human Values 2002, 19, 39-51.

15. Zepeda, L.; Leviten-Reid, C. Consumers' views on local food. J. Food Distrib. Res. 2004, 35, 1-6.

16. Selfa, T.; Qazi, J. Place, taste or face-to-face? Understanding producer-consumer networks in "local" food systems in Washington State. Agric. Human Values 2005, 22, 451-464.

17. Whole Foods Market. Locally Grown-The Whole Foods Market Promise; Available online: http://www.wholefoodsmarket.com/products/locallygrown/index.html (accessed on 31 May 2008).

18. The Hartman Group. Consumer understanding of buying local. HartBeat Newsletter, 27 February 2008; Available online: http://www.hartman-group.com/hartbeat/2008-02-27 (accessed on 1 June 2008).

19. LocalHarvest Home Page. Available online: http://www.localharvest.org/ (accessed on 25 October 2009).

20. Center for Great Plains Studies; Available online: http://www.unl.edu/plains/index.shtml (accessed on 31 May 2008).

21. Champion, B.L. The Political Economy of "Local Foods" in Eastern Kansas: Opportunities and Justice in Emerging Agro-Food Networks and Markets; Ph.D. Thesis, Balliol College, Oxford University, Oxford, UK, 2007.

22. Endicott, D. Our Story; Available online: http://www.goodnatured.net/our_story/story.html (accessed on 1 June 2008).

23. Qazi, J.; Selfa, T. The politics of building alternative agro-food networks in the belly of agro-industry. Food Cult. Soc. 2005, 8, 45-72.

24. Food CPI, Prices and Expenditures: Food Expenditure Tables; Economic Research Service, US Department of Agriculture: Washington DC, USA, 2008; Available online: http://www. ers.usda.gov/Briefing/CPIFoodAndExpenditures/data/ (accessed on 2 June 2009).

25. Izumi, B.; Wright, D.W.; Hamm, M. Farm to School Programs: exploring the role of regionally-based food distributors in alternative agrifood networks. Agric. Human Values 2009, doi:10.1007/s10460-009-9221-X.

26. Morgan, K.; Sonnino, R. The School Food Revolution: Public Food and the Challenges of Sustainable Development; Earthscan Publications: London, UK, 2008.

27. Allen, P.; Guthman, J. From "old school" to "farm-to-school": neoliberalization from the ground up. Agric. Human Values 2006, 23, 401-415. 
28. Kloppenburg, J.; Hassanein, N. From old school to reform school? Agric. Human Values 2006, 23, 417-421

29. Kalb, M. National farm to school network takes root. Community Food Secur. News 2008, 1, 12.

30. Bagdonis, J.M.; Hinrichs, C.; Schafft, K. The emergence and framing of farm-to school initiatives: civic engagement, health and local agriculture. Agric. Human Values 2009, 26, 107-119.

31. Vogt, R.; Kaiser, L. Still time to act: a review of institutional marketing of regionally-grown food. Agric. Human Values 2008, 25, 241-255.

32. Gregoire, M.B.; Arendt, S.W.; Strohbehm, C.H. Iowa producers' perceived benefits and obstacles in marketing to local restaurants and institutional foodservice operations. J. Ext. 2005, 43, 1; Available online: http://www.joe.org/joe/2005february/rb1.php (accessed on 23 October 2009).

33. Conner, D.S.; Montri, A.D.; Montri, D.N.; Hamm, M.W. Consumer demand for local produce at extended season farmers' markets: guiding farmer marketing strategies. Renew. Agr. Food Syst. 2009, doi:10.1017/S1742170509990044.

34. 2007 Census of Agriculture; National Agricultural Statistical Service, US Department of Agriculture: Washington DC, USA, 2009; Available online: http://www.agcensus.usda.gov/ Publications/2007/Full_Report/usv1.pdf (accessed on 24 October 2009).

35. Gregoire, M.B.; Strohbehm, C. Benefits and obstacles in purchasing food from local growers and producers. J. Child Nutr. Manag. 2002, 26, 1-7.

36. Hoppe, R.A.; Korb, P.; O’Donoghue, E.J.; Banker, D.E. Structure and Finances of U.S. Farms: Family Farm Report, 2007 Edition; Economic Information Bulletin No. 24; Economic Research Service, United States Department of Agriculture: Washington, DC, USA, 2007; Available online: http://www.ers.usda.gov/ Publications/EIB24/ (accessed on 30 October 2009).

37. Berkenkamp, J. Making the Farm/School Connection: Opportunities and Barriers to Greater Use of Locally-Grown Produce in Public Schools; Department of Applied Economics, University of Minnesota: Minneapolis, MN, USA 2006; Available online: http://www.cifap.umn.edu/ publications/Berkenkamp\%20Feasibility\%20final\%20paper.pdf (accessed on 23 October 2009).

38. McFadden, D. Conditional logit analysis of qualitative choice behavior. In Frontiers in Econometrics; Zarembka, P., Ed.; Academic Press: New York, NY, USA, 1973; pp. 105-142.

39. Strohbehm, C.H.; Gregoire, M.B. Local Foods: From Farm to College and University Foodservice; 2005; Available online: https://www.extension.iastate.edu/NR/rdonlyres/ B0D64A49-9FA9-410E-849A-31865EFECE91/65253/manuscript2004003final_version.pdf (accessed on 24 October 2009).

40. Healthy Community Design and Access to Healthy Food Legislation Database; National Conference of State Legislatures: Washington, DC, USA, 2009; Available online: http://www. ncsl.org/?tabid=13227 (accessed on 9 December 2009).

41. Lebel, L.; Lorek, S. Enabling sustainable production-consumption systems. Annu. Rev. Environ. Resour. 2008, 3, 241-275.

(C) 2010 by the authors; licensee Molecular Diversity Preservation International, Basel, Switzerland. This article is an open-access article distributed under the terms and conditions of the Creative Commons Attribution license (http://creativecommons.org/licenses/by/3.0/). 